\title{
Transatlantica
}

Revue d'études américaines. American Studies Journal

1 | 2021

Line Breaks in America: the Odds and Ends of Poetry

\section{Frèsh critique}

\section{Vincent Broqua}

\section{(2) OpenEdition}

Journals

Édition électronique

URL : https://journals.openedition.org/transatlantica/17284

DOI : 10.4000/transatlantica. 17284

ISSN : 1765-2766

Éditeur

Association française d'Etudes Américaines (AFEA)

Référence électronique

Vincent Broqua, «Frèsh critique », Transatlantica [En ligne], 1 | 2021, mis en ligne le 01 juillet 2021, consulté le 17 février 2023. URL : http://journals.openedition.org/transatlantica/17284 ; DOI : https:// doi.org/10.4000/transatlantica.17284

Ce document a été généré automatiquement le 17 février 2023.

\section{(c) (i) $\odot$}

Creative Commons - Attribution - Pas d'Utilisation Commerciale - Pas de Modification 4.0 International - CC BY-NC-ND 4.0

https://creativecommons.org/licenses/by-nc-nd/4.0/ 


\section{Frèsh critique}

\section{Vincent Broqua}

Frèsh critique : [à l'étouffée]

Souffle

coupe

\section{Colonne}

sèche

Fumée

panachée

le spectacle

ordinaire

des

orgues

raccourcies

contra

dic

toi 
jeux faciles

formes graciles

"nous

assistons

à un

spect

acle uni

que

dans la

po

é

sie on

ne chante

plus

au

lutrin

on ne

s'ac

compagne

plus des

gran

des or 
gues du

ma

ître [mètre]

off

i

ciel"

ces

soufflés

mode

cuisant

ratés

qui

retombent

on les

crise

d'appétit

à

l'étouffée

frèsh critique : [jambements] 
en

coller

des

prostitutions

entre

jambements

biens

de fins

ça tortille

oui ça

dra / ma/ tise

ça fait ça

ressortir

les

mots

morts ça

les plante

les projets

tire

dérive

puissance

grondante 
plage critique

\section{AUTEUR}

VINCENT BROQUA

Université Paris 8, TransCrit (EA1569) 